\title{
Addendum: Deamer, D. Where Did Life Begin? Testing Ideas in Prebiotic Analogue Conditions. Life 2021, 11, 134
}

\section{David Deamer}

check for updates

Citation: Deamer, D. Addendum: Deamer, D. Where Did Life Begin? Testing Ideas in Prebiotic Analogue Conditions. Life 2021, 11, 134. Life 2021, 11, 613. https://doi.org/ 10.3390/life11070613

Received: 22 June 2021

Accepted: 23 June 2021

Published: 25 June 2021

Publisher's Note: MDPI stays neutral with regard to jurisdictional claims in published maps and institutional affiliations. $4.0 /)$.

\footnotetext{
Copyright: (C) 2021 by the author. Licensee MDPI, Basel, Switzerland. This article is an open access article distributed under the terms and conditions of the Creative Commons Attribution (CC BY) license (https:// creativecommons.org/licenses/by/

(C)
}

Department of Biomolecular Engineering, University of California, Santa Cruz, CA 95060, USA; deamer@soe.ucsc.edu

\section{Addendum}

The author wishes to add the following information to the acknowledgements section of his paper published in Life [1].

The author thanks Kathleen Campbell and her students and staff for organizing the field work in New Zealand, and Bruce Damer for his collaborative efforts in the ongoing research. The author also thanks the staff at Hell's Gate for their help and support in conducting the field work. The author greatly appreciated the assistance of UNSW graduate student Luke Steller in obtaining samples, and transportation to and from the site by Bryan Drake.

\section{Reference}

1. Deamer, D. Where Did Life Begin? Testing Ideas in Prebiotic Analogue Conditions. Life 2021, 11, 134. [CrossRef] [PubMed] 